San Jose State University

From the SelectedWorks of Meekyung Han

2011

Risk and Protective Factors Contributing to Depressive Symptoms in Vietnamese American

College Students

Meekyung Han, San Jose State University

Mary Lee, Fulbright Institute of International Education 


\section{Risk and Protective Factors Contributing to Depressive Symptoms in Vietnamese American College Students}

Meekyung Han Mary Lee

With the demographic shifts the United States faces, understanding the contributing factors to mental well-being among minority college students is crucial. This study examines the roles of parental and peer attachment, intergenerational conflict, and perceived racial discrimination on depressive symptoms while also analyzing the mediational role of sense of coherence (SOC) on depressive symptoms in Vietnamese American college students. Results from 134 Vietnamese American students surveyed showed that higher levels of parental and peer attachment predicted lower depressive symptoms; SOC partially mediated the effect of parental attachment on depressive symptoms; and SOC played a full mediational role via perceived racial discrimination on depressive symptoms. These findings provide implications for interventions targeting Vietnamese American students at institutions of higher education.

Southeast Asians (SEAs), including the Vietnamese, began arriving in the United States in large numbers as refugees at the conclusion of the Southeast Asian Wars in 1975, and there are an estimated 2.3 million SEAs living in the country (U.S. Census Bureau, 2003). Among SEAs, the Vietnamese, including Vietnamese Americans, form the largest group (Southeast Asian Reaction Center, 2004) and are among the fastest growing populations in the US. (U.S. Census
Bureau, 2006). Accordingly, a good deal of the extant research has examined the psychological functioning of this refugee population. In fact, the study of war trauma and its important role in mental health problems among SEA adult refugee populations has received considerable attention in the past three decades to the point that there is now substantial knowledge about rates of trauma and associated problems (Hsu, Davies, \& Hansen, 2004; Marshall, Schell, Elliott, Berthold, \& Chun, 2005; Ying, 2001). While this research has been limited to adult refugee populations, very few studies have been conducted on the psychological well-being of their children, Vietnamese Americans in general, and those who are in higher education in particular. In this study Vietnamese American is defined as an American of Vietnamese descent who was born to refugee parents in America (so called second generation) or who immigrated to America before or during their early teens (so called 1.5 generation). These Vietnamese American populations make up about half of the American communities of Vietnamese, which is the third largest Asian American group in this country (U.S. Census Bureau, 2006). We sought to fill such gaps in the literature by studying Vietnamese American college students' mental health as measured by depressive symptoms to discern the implications for student affairs professionals to promote mental health and

Meekyung Han is Assistant Professor of Social Work at San Jose State University. Mary Lee is a researcher at the Fulbright Institute of International Education. This study was partially supported by a faculty research grant given to the first author from the California State University Research Grant. Vicki Chow, Maudon Nguyen, and SangHee Novotny assisted with the data collection. 
well-being for these students (and potentially those with similar backgrounds) in campus settings.

As many Vietnamese American students are the first in their families to enter college, they experience inordinate pressure to perform and meet their parents' expectations to succeed academically for the purpose of social and economic mobility (Suzuki, 2002), which may adversely impact these students' psychological well-being. Indeed, empirical studies show that Vietnamese American college students suffer from higher depressive symptoms compared to other Asian students in college (Han, Chou, Novotny, \& Nguyen, 2007). However, the factors that may precipitate and minimize depressive symptoms among Vietnamese American college students have not been fully studied. Understanding the contributing factors on depressive symptoms is a critical primary component to enhancing the overall psychological well-being of Vietnamese American college students, since empirical studies with the general population have found that depressive symptoms are related to virtually every other psychological concept or domain, such as low self-esteem, suicidal behavior, suicidal ideation, completed suicide, alcohol abuse, conduct disorder, and anger and aggression (for review, see Abela \& Hankin, 2008). Given the significant likelihood of depressive symptoms on other risk behaviors, a better understanding of the factors that contribute to and/or guard against depressive symptoms among Vietnamese American college students would provide significant implications for educators and other professionals in institutions of higher education.

In light of the literature review, this study examines whether well-developed contributing factors-as demonstrated with other ethnic minority adolescents—such as (a) parental and peer attachment, (b) intergenerational conflict, (c) perceived racial discrimination
(PRD), and (d) sense of coherence as a mediator on mental health, would contribute to Vietnamese American college students' depressive symptoms. More specifically, we sought to answer the following research questions:

- What is the role of parental and peer attachment on depressive symptoms?

- What is the role of intergenerational conflict and perceived racial discrimination on depressive symptoms?

- What is the role of sense of coherence on depressive symptoms? And does it mediate the effect of life stressors on depressive symptoms?

Below is a description of Vietnamese American college students in the United States and a literature review on the relationship between the aforementioned predictors and psychological well-being as measured by depressive symptoms and sense of coherence.

\section{Vietnamese American College Students}

According to the U.S. Census (2003), most Vietnamese American college students are either 1.5-generation immigrants who accompanied their parents on their journey to the US as refugees or second-generation children born to refugee parents. These children have since aged into young adults and many have entered the college education system in America. Probably due to their low population in the US, Vietnamese American students are commonly categorized as Asian Pacific Islanders (API), who are often cited as a model minority with high academic achievements with nonexistent problems (e.g., mental and/or behavioral) in higher education. Although sharing similar cultural values (Sue \& Sue, 2009), Vietnamese American college students, as children of refugees, are distinct from other API college students who are children of immigrants, and 
they require different academic and social support in the college setting. Also, contrary to the general assumption, Vietnamese Americans are severely underrepresented in institutions of higher education as are other Southeast Asians (Um, 2003). Vietnamese American students suffer from more psychological distress than other Asian subgroups (Han, Chou, Novotny, \& Nguyen, 2007). For example, universities in the California state system report higher percentages of Asian populations (over $41 \%$ across the system), but very low Vietnamese American student enrollment (on average about $7 \%$ of the students enrolled), despite its proximity to some of the largest Vietnamese American communities in the United States, such as Los Angeles, Orange County, and the San Francisco Bay area where nearly $40 \%$ of the entire Vietnamese American population resides (U.S. Census Bureau, 2006). Low Vietnamese American participation in higher education also reflects the group's low education level: According to 2003 U.S. Census data, 17.0\% of Vietnamese Americans aged 25 and over reported holding a bachelor's degree, compared to $61.5 \%$ of APIs and $26.7 \%$ of Americans overall in that age group.

\section{PARENTAL AND PEER ATTACHMENT AND DEPRESSIVE SYMPTOMS}

A central aspect of attachment theory is the notion that infants construct models of relationships out of interactions with caregivers, mostly parents (Bowlby, 1988). The idea that attachment is an essential ingredient for healthy human development has been fortified by the increasing attention in applying attachment theory to areas of the life span beyond infancy (Kenny \& Sirin, 2006). Studies have found that people continue to develop in view of attachmentrelated experiences throughout childhood, adolescence, and early adulthood (Hunnum
\& Dvorak, 2004; Lopez \& Brennan, 2000). Numerous empirical studies have demonstrated that attachment to parents is a strong predictor for a variety of college adjustment issues, including social, academic, and personal/ psychological functioning (Hinderlie \& Kenny, 2002), perceived stress and coping styles (McCarthy, Moller, \& Fouladi, 2001), and social competence (Rice, Fitzgerald, Whaley, \& Gibbs, 1995).

Further evidence confirming these trends for immigrant populations, including Asian American and Vietnamese American groups, would provide insight into the interplay of race, ethnicity, and culture on attachment phenomena (Han, 2004; Mallinckrodf, 2000; Mikulincer \& Arad, 1999; Zevalkink, RiksenWalraven, \& Bradley, 2008). More generally for risky adolescent behaviors, one study found that attachment between Asian American parents and adolescents had a moderating effect on adolescent alcohol use (Hahm, Lahiff, \& Guterman, 2003).

Similar to parental attachment, a growing number of empirical research support a unique and positive role of peer attachment on emotional well-being and adjustment among college students (Greenberg, Siegel, \& Leitch, 1984; Laible, Carlo, \& Raffaelli, 2000). Despite yearning for greater independence, college students also want to be accepted and validated by others, particularly by their peers who begin to serve as significant and influential attachment figures (Laible, Carlo, $\&$ Roesch, 2004). Thus, it is clear that, just as with parents, peer attachment can likely be an important factor in the development of depressive symptoms in college students.

\section{Intergenerational Conflict, Racial Discrimination, and Depressive Symptoms}

Based on the ecological perspective, a college student's development is enhanced by resources 
and enhanced or depreciated by environments in multisystems that the college student is directly involved in (e.g., home and school). Arnett (1999) asserted that intergenerational gaps occur as a result of normal child development and are universal. Within the general population, most intergenerational conflicts seem to occur owing to the developmental processes that manifest over mundane issues, such as doing chores and one's appearance, which may not necessarily have significant detrimental impact on a child's mental health (Steinberg, 2001). However, the term intergenerational conflict in immigrant families has a distinctive feature that describes the far greater condition of relational conflict due to the cultural and value dissonance between immigrant parents and their children (Choi, He, \& Harachi, 2008). As a matter of fact, over the past two decades, extensive research has shown the negative effects of intergenerational conflict on the mental health of Asian American families in general (Chung, 2001; Lee, 2003; Lee, Cho, Kim, \& Ngo, 2000; Ying \& Tracy, 2004) and in SEA families, including Vietnamese (Dinh, Sarason, \& Sarason, 1994; Kibria, 1993; Ying \& Han, 2007; Zhou \& Bankston, 1998).

The fact that racial discrimination, either perceived or experienced, is a unique life stressor to ethnic/racial minorities has been well documented (Clark, Anderson, Clark, \& Williams, 1999; Garcia Coll et al., 1996; Major et al., 2002; Thompson \& Neville, 1999). With regard to the college population, the majority of the existing empirical studies on the negative impact of perceived racial discrimination has focused on African American students (Nyborg \& Curry, 2003; Scott, 2003) and Hispanic students (Stone \& Han, 2005; Szalacha et al., 2004). However, more recent studies show the consistent negative effect of racial discrimination on mental health with Asian American adolescents (Liang, Li, \& Kim,
2004; Ying, Lee, \& Tsai, 2000) and Vietnamese American college students (Lam, 2007).

\section{SENSE OF COHERENCE AND ITS MEDIATING ROLE}

According to Antonovsky (1979), a sense of coherence directly and positively impacts a person's mental health and mediates the influence of life stressors and coping resources on psychological well-being. Based on a "salutogenic model," sense of coherence is defined as:
A global orientation that expresses the extent to which one has a pervasive, enduring through dynamic feeling of confidence, that (1) the stimuli deriving from one's internal and external environments in the course of living are structured, predictable, and explicable (comprehensibility); (2) the resources are available to one to meet the demands posed by these stimuli (man- ageability); and (3) these demands are challenges, worthy of investment and engagement (meaningfulness). (Antonovsky, 1987, p. 218)

Simply put, while sense of coherence does not determine explicit behavior, it does impact the perception and interpretation of external events in one's life space as more or less ordered, predictable, and manageable. Therefore, a person with strong sense of coherence often shows good mental health. Previous studies have also shown that sense of coherence serves as a significant mediator between life stressors and psychological adjustment with White populations (Antonovsky \& Sagy, 1986; von Bothmer \& Fridlund, 2003) and with Asian American college students (Han, 2004; Lam, 2007).

Furthermore, sex was included as a control variable in this study. Both Asian and White female adolescents and young adults have been found to report higher levels of depressive symptoms than their male peers. (Greenberg, Chen, 
Tally, \& Dong, 2000; Hankin et al., 1998; Nolen-Hoeksema \& Girgus, 1994). With regard to other demographic variables, the literature has suggested that family socioeconomic status (SES) and age are proxy indicators. For example, studies showed that sense of coherence developed from life experiences beginning in childhood was likely to be influenced by personal (e.g., age) and family characteristics (e.g., family SES; Sagy \& Antonovsky, 2000), and that disadvantaged SES contributed to poor mental health, especially depression, in children (Leinonen, Solantaus, \& Punamaki, 2002).

\section{METHODS}

\section{Sample and Procedures}

Using a cross-sectional design and a convenience sampling method, 134 Vietnamese American college students attending a public university in Northern California were recruited. To generate as large a sample of Vietnamese American students as possible, a variety of recruitment methods were employed. Participants were recruited through Vietnamese American student organizations, publicly posted fliers, announcements in classes, and by word of mouth. All participation was voluntarily in this study. Participants filled out a paper-pencil survey, which included demographic questions along with the instruments containing the study variables.

Out of 134 Vietnamese American college students, females accounted for $57.3 \%$ of the sample, and males $42.7 \%$. The students' age ranged from 18 to 25 years, with a mean student age of 21.44 years $(S D=1.50)$, and their mean years in college was $3.52(S D=1.07): 5.4 \%$ freshman, $7.7 \%$ sophomore, $36.9 \%$ junior, $30.8 \%$ senior, and $19.3 \%$ 5th-year students. Among them, 56.7\% were born outside of the United States, with a mean age of migration being 8.36 years $(S D=4.73)$ and an average residence in the US of 13.15 years $(S D=4.73)$.
More than half of the participants (51.7\%) reported an annual family income below $\$ 50,000$. Their fathers' and mothers' education levels ranged from no education at all to postmaster's level, with a mean of 11.91 years of education $(S D=4.45)$ for fathers and a mean of 10.69 years $(S D=4.42)$ for mothers.

\section{Measures}

Inventory of Parental and Peer Attachment (IPPA). Parental and peer attachment was measured by the IPPA, developed by Amrsden and Greenberg (1987) to assess the security of attachment. The IPPA consists of two scales that are scored independently: the Parents scale (28 items) and the Peers scale (25 items). This questionnaire empirically examined students' perceived attitudes and behaviors of parents and peers. Parent attachment was measured with sample items such as, "I can count on my parents when I need to get something off my chest." Peer attachment was measured with sample items such as, "My friends are concerned about my well-being." The items were measured on a 4-point scale: 1 (always true), 2 (often true), 3 (seldom true), and 4 (never true). The students completed one of these in regards to their parents and also one in regards to their peers; higher scores represented higher parental or peer attachment. Previous studies show the reliability and validity of the instrument with the Asian population (Han et al., 2007). Both scales were shown to be reliable in the current study ( $\alpha=.91$ for Parents and $\alpha=.92$ for Peers).

Sense of Coherence (SOC). The 13-item SOC, which was developed and presented by Antonovsky (1987) to measure perceived competence as well as resiliency, was used for this study to measure the level of resiliency and sense of coherence. Responses to the questions were coded on a 7-point Likert-type scale ranging from 1 (never) to 7 (always); the individual items were summed to yield the 
SOC sum score, with higher scores indicating a greater coherence. Pallant and Lae (2002) supported the SOC's reliability and validity using a community-based sample. In this study, the SOC scale was also shown to be reliable $(\alpha=.87)$.

Center for Epidemiological Studies-Depression Scale (CES-D). Depressive symptom was measured by the 20-itemCES-D (Radloff, 1977). Participants were asked to report how many times they had experienced each symptom in the past week on a 4-point scale: 0 (Rarely or none of the time [less than 1 day a week]), 1 (some of the time [1 or 2 days a week]), 2 (Occasionally [3 or 4 days a week]), and 3 (Most or all the time [5-7 days a week]), It has been shown to have good psychometric properties in Asian American college students (Ying, Lee, Tsai, Yeh, \& Huang, 2000), and in our sample, its internal reliability was .90 .

Asian American Conflicts Scale (AAFC). Intergenerational conflict was measured by the AAFC (Lee et al., 2000), developed to assess family conflict in Asian American immigrant families. The 10-item measure portrayed potential situations of disagreement in values and practices, such as, "Your parents tell you what to do with your life, but you want to make your own decision." Participants were asked to rate each statement with regard to both likelihood (from 1 [almost never] to 5 [almost always]) and seriousness (from 1 [not at all] to 5 [extremely]). A previous study reported AAFC's high reliability and strong validity in Asian American college students (Lee et al.). The current study sample also showed the instrument had very good internal reliability $(\alpha=.90)$.

Perceived Racial Discrimination. There are a variety of approaches used in the literature for measuring perceived racial discrimination, ranging from single-item indicators to composite measures (e.g., Landrine \& Klonoff, 1996). Using Dion's (2003) conceptualization of perceived discrimination, we asked students about discrimination directly, asking how much students felt they were subject to racial discrimination on campus on a 5-point scale, from 1 (not at all) to 5 (all the time).

\section{Demographic Information}

Student's demographic information served as control variables. Gender was coded 1 for female and 0 for male. Family SES was measured by estimated family income, with 1 for less than \$4,999; 2 for $\$ 5,000-7,499 ; 3$ for $\$ 7,500-9,999,4$ for $\$ 10,000-14,999 ; 5$ for $\$ 15,000-19,999 ; 6$ for $\$ 20,000-24,999$; 7 for $\$ 25,000-34,999$; 8 for $\$ 35,000-49,999$; 9 for $\$ 50,000-74,999 ; 10$ for $\$ 75,000-99,999 ; 11$ for $\$ 100,000-199,999$; and 12 for $\$ 200,000$ or more.

\section{ANALYSIS}

To answer the first and second research questions, zero-order correlations between the predictor variables (parental attachment, peer attachment, intergenerational conflict, perceived racial discrimination) and the outcome variable (depressive symptoms) were used. To answer the last research question, Baron and Kenny's (1986) three-step approach to test mediation was used as an analytic strategy. According to Baron and Kenny, mediation is established when (a) the independent variable(s) significantly predicts the dependent variable (depressive symptoms in this study), (b) the independent variable(s) significantly predicts the mediator variable (sense of coherence in this study), and (c) the effect of the independent variable(s) on the dependent variable is reduced when the mediator variable is controlled for. More specifically, mediation occurs if the independent variable in the third step becomes no longer significant (full mediation) or reduced in comparison with the first equation (partial mediation). Thus, several 
TABLE 1.

Correlations Among Variables

\begin{tabular}{lcccccc}
\hline Variables & $\begin{array}{c}\text { Parental } \\
\text { Attachment }\end{array}$ & $\begin{array}{c}\text { Peer } \\
\text { Attachment }\end{array}$ & $\begin{array}{c}\text { Intergen. } \\
\text { Conflict }\end{array}$ & $\begin{array}{c}\text { Perceived } \\
\text { Racial } \\
\text { Discrim. }\end{array}$ & $\begin{array}{c}\text { Sense of } \\
\text { Coherence }\end{array}$ & $\begin{array}{c}\text { Depressive } \\
\text { Symptoms }\end{array}$ \\
\hline $\begin{array}{l}\text { Parental } \\
\text { Attachment }\end{array}$ & 1.00 & .01 & $-.47^{* * *}$ & -.05 & $.24^{* *}$ & $-.28^{* * *}$ \\
$\begin{array}{l}\text { Peer Attachment } \\
\text { Intergenerational }\end{array}$ & & - & .04 & $-.20^{*}$ & $.25^{* *}$ & $-.34^{* * *}$ \\
$\begin{array}{l}\text { Conflict } \\
\text { Perceived Racial }\end{array}$ & & - & .11 & $-.23^{* *}$ & $.21^{* *}$ \\
$\begin{array}{l}\text { Discrimination } \\
\text { Sense of }\end{array}$ & & & & - & $-.25^{* * *}$ & $.29^{* * *}$ \\
Coherence & & & & & - & $-.48^{* * *}$ \\
$\begin{array}{l}\text { Depressive } \\
\text { Symptoms }\end{array}$ & & & & & & 1.00 \\
Mean $(S D)$ & $2.52(0.39)$ & $2.93(0.39)$ & $1.53(0.43)$ & $2.07(1.13)$ & $4.26(0.70)$ & $0.90(0.47)$ \\
Range & $1-5$ & $1-5$ & $1-5$ & $1-5$ & $1-7$ & $0-3$ \\
\hline
\end{tabular}

$* p<.05 . * * p<.01 . * * * p<.001$, two-tailed tests.

regression analyses were conducted and the significance of the coefficients was examined at each step.

\section{RESULTS}

In response to the first research question, the relationship between parental and peer attachment and depressive symptoms was shown in the results of correlation that a higher degree of parental attachment and peer attachment were negatively associated with depressive symptoms $(r=-0.28, p<.001$, and $r=-0.34$, $p<.001$, two-tailed test, respectively). In terms of the roles of perceived racial discrimination (PRD) and intergenerational conflict on depressive symptoms (the second research question), the results of correlation indicate that both seem to serve as life stressors among Vietnamese American college students. More specifically, intergenerational conflict was positively associated with depressive symptoms $(r=0.21, p<.001$, two-tailed test) and PRD was also positively associated with depressive symptoms $(r=0.29, p<.001$, two-tailed test). These results are consistent with existing studies on the negative impact of both intergenerational conflict and PRD on mental health among ethnic minorities. The results also showed that a higher sense of coherence was associated with the lower level of depressive symptoms $(r=-0.48, p<.001$, two-tailed test). See Table 1.

To further examine the impact of parental and peer attachment, intergenerational conflict, and PRD on depressive symptoms, and to test the aforementioned mediational role of sense of coherence, we carried out multivariate analyses utilizing multiple regression based on Baron and Kenny's mediational model test approach. As shown in Table 2, by focusing on the results of Step 3 (full model), the results showed that (a) as expected, higher levels of parental and peer attachment predicted lower depressive symptoms (standard coefficient $=-0.31$, $p<.01$ and standard coefficient $=-0.25$, 
$p<.05$, one-tailed test, respectively); (b) sense of coherence partially mediated the effect of parental attachment on depressive symptoms; and (c) sense of coherence played a full mediational role of PRD on depressive symptoms. As a further test of the mediational role of sense of coherence between PRD and parental attachment and depressive symptoms, Sobel tests were conducted for these variables (Sobel, 1982, cited in Baron \& Kenny, 1986). A significant Sobel test indicated that the relationship between PRD and depressive symptoms has been significantly reduced by the inclusion of sense of coherence $(z=2.27$, $p<.05)$ and sense of coherence mediates the impact of parental attachment on depressive symptoms $(z=-1.74, p<.05)$.

Unlike the existing literature on the pertinent effect of intergenerational conflict, our participants reported no significant consequences of intergenerational conflict on depressive symptoms after taking into account other independent variables.

\section{DISCUSSION}

Congruent with the existing studies, the study found that the students who experienced higher levels of parental and peer attachment-in other words, students who felt cared for by their parents and friends-also experienced lower levels of depressive symptoms after controlling for intergenerational conflict, PRD, and student's demographic information. The result supported the application of Bowlby's (1973) attachment theory to the Vietnamese American college student population in northern California. Bowlby stated that parents who provide children with secure attached relationships also provide them with the assurance that they are trustworthy and worthy of being loved and cared for. As they mature, these children are likely to become self-confident and emotionally healthy adolescents, without any insecure attachment links to the vulnerability to stress (Kenny \& Donaldson, 1991; Merz, Schuengel, \& Schulze, 2007). Also, the findings suggest

TABLE 2.

Standardized $\beta$ Coefficients of Variables

\begin{tabular}{|c|c|c|c|}
\hline & Step 1 & Step 2 & Step 3 \\
\hline Dependent Variable & $\begin{array}{l}\text { Depressive } \\
\text { Symptoms }\end{array}$ & $\begin{array}{l}\text { Sense of } \\
\text { Coherence }\end{array}$ & $\begin{array}{l}\text { Depressive } \\
\text { Symptoms }\end{array}$ \\
\hline Adjusted $R^{2}$ & .24 & .19 & .29 \\
\hline$F$ & $4.92 * * *$ & $3.78 * * *$ & $5.19 * * *$ \\
\hline Parent Attachment & $-.38 * *$ & $.23 *$ & $-.31 * *$ \\
\hline Peer Attachment & $-.29 *$ & .11 & $-.25^{*}$ \\
\hline Intergenerational Conflict & .06 & $-.17 *$ & .01 \\
\hline Perceived Racial Discrimination & $.14^{*}$ & $-.26 * *$ & .10 \\
\hline Sense of Coherence & - & - & $-.30 * *$ \\
\hline Being Female & .01 & .04 & .01 \\
\hline Age & -.14 & .15 & -.08 \\
\hline Family SES & .07 & .11 & .11 \\
\hline
\end{tabular}

$* p<.05 . \quad * * p<.01 . \quad * * * p<.001$, one-tailed tests. 
that peers as attachment figures may be just as influential for Vietnamese American college students in promoting their psychological well-being, echoing the existing literature that shows peers may be as important as attachment figures in adolescence.

The study also supported the previous empirical studies about the direct detrimental consequence of PRD on mental health (Dion, 2002; Lam, 2007; Ying, Lee, \& Tsai, 2000). In addition, as shown in Table 2 , this study showed that the impact of PRD on depressive symptoms was rather mediated by sense of coherence. This indicates that as a relatively common phenomenon among ethnic minority college students, the experience of discrimination can be a powerful negative correlate of cognitive controllability on one's environment and a positive correlate with self-doubt. The experience of discrimination further creates a negative cognitive reaction toward these students' sense of coherence, which consequently impacts depressive symptoms.

In terms of intergenerational conflict, although there is an association between intergenerational conflict and depressive symptoms, after controlling for other factors, intergenerational conflict did not predict depressive symptoms. In view of its effect on sense of coherence (as shown in Table 2), however, it appeared that children who experience intergenerational conflict may feel that they do not have a sense of control over their own lives. This results in lowered sense of coherence which might increase depressive symptoms rather than directly effecting depressive symptoms. Also as Phinney and Ong (2002) noted, lack of emotional closeness and interaction with their parents (i.e., feeling a lack of caring and understanding from their parents) may be what leads to poor mental health among Vietnamese American college students rather than intergenerational conflict per se.

This study supported the mediational role of sense of coherence on depressive symptoms with Vietnamese American college students. This indicates that the study contributed to broaden the applicability of sense of coherence to the Vietnamese American young adults with regards to its relationship with mental health. In other words, a college student with better sense of coherence skills would be more effective at self-management skills and, in turn, would more likely be psychologically healthy. The finding shows that sense of coherence mediated the effects of parental attachment on Vietnamese American college students' depressive symptoms. The current finding also confirms previous studies showing that sense of coherence is an important mediator between adversity, such as perceived racial discrimination, and psychological well-being. As Carstens and Spangenberg (1997) asserted, the current study provided additional support for understanding depression as a breakdown in sense of coherence.

\section{Study Limitations}

The results of this study should be interpreted with caution due to several limitations. First, the sample was composed entirely of undergraduates attending a 4-year college in the San Francisco Bay Area. This limits the representativeness and the generalizability of the study's findings, though it is noteworthy that the region has a high concentration of Vietnamese Americans compared to the rest of the nation. The study's sampling method also limits the generalizability of the findings to other Vietnamese American college students. For example, individuals who participated in this study were a self-selected group who could be quite different from those choosing not to participate. To have more generalizable findings, future studies should recruit a more representative sample of Vietnamese American young adults across education levels and geographical locations. Second, our findings 
are limited due to the cross-sectional research design. With a cross-sectional design, it is impossible to draw any definitive conclusions about the causal effects of variables used in this study. Third, this study did not include other important factors, such as social support. This may be especially relevant to Vietnamese Americans because their culture emphasizes familism and collectivism. Future research should address its contribution to their wellbeing. Lastly, the operationalization of PRD which was measured by a single item in this study is also a limitation. The problem with single indices lies in presuming that the subject's self-reported perceived racial discrimination on one item can fully account for the multifaceted complexities of racial discrimination. At best, such indices can be proxy measures in which perceived racial discrimination is implied rather than ascertained directly. Future research may strengthen the results by using an instrument like the Asian American Racism-Related Stress Inventory (Liang, Li, \& Kim, 2004).

\section{Implications for Intervention}

Despite the limitations, this study holds several important implications for both social service providers and student affairs professionals in higher education. As findings show, Vietnamese American college students may benefit from emotional closeness with parents; therefore social service providers should work on enhancing intergenerational relationships in Vietnamese American families to promote attachment and diminish conflict. For example, social service agencies working with the Vietnamese American community could partner with college administrators in the community in offering workshops and events for parents of college students to strengthen their relationships with their young adult children, both prior to and during college. These could also include various psychoeducational workshops that provide students with information about the relationship between family dynamics and their current social and psychological distress. Beyond the typical sports and entertainment events during parents' weekend at universities, it is important to organize activities for families that engage parents and college students in meaningful dialogue about a variety of relationship issues.

The study also found that promoting the development and maintenance of positive peer relationships and emotional closeness is paramount to the success of Vietnamese American students in the college setting. Vietnamese Americans attending college are often first-generation students or transfer students from 2-year institutions who enter college with limited resources and are limited in peer interactions with other students (Um, 2003). Offering activities and workshops to promote social skills and familiarity with the institution's resources as well as providing more culturally sensitive peer mentorship programs would encourage these students to actively participate in mainstream student organizations and/or increase peer connections (Alvarez \& Liu, 2002; Suzuki, 2002). In addition, as Yeh (2002) asserts, it is crucial for recruitment and admissions staff to support prospective first-generation Asian American students and their families by providing information and resources for residing in campus residence halls. Vietnamese parents unfamiliar with college lifestyles in the US often fear the prospect of their children leaving home, preventing many students from living on campus. Yet, many of these students would experience positive integration into the school environment and thus enhance their developmental experience by interacting with student peers (Yeh). Therefore, in order to support the development of peer attachments among Vietnamese American college students, outreach initiatives involving parents is 
important for such students and their families as well as peer-based and peer-driven activities to help orient incoming first-year and transfer students. Bilingual/bicultural staff able to comfortably interact with both parents and students are needed to assess and provide appropriate information, in addition to dispelling fears about on-campus living. Students and parents must have access to orientation and advising sessions so that they can become familiar with college procedures.

In light of this study's finding on the significant direct and indirect effects of perceived racial discrimination on depressive symptoms, interventions that address cultural diversity in general and racial discrimination in particular are needed. Campus initiatives and other interventions focusing on promoting intercultural competence are needed to strengthen the connection between knowledge about other cultures and interaction with other cultures without prejudice and discrimination (King \& Baxter Magolda, 2005). Also, as Alvarez and Liu (2002) encourage, intervention must additionally occur in the college classroom as part of the learning environment. Student affairs staff ought to collaborate with faculty to create curricula with dynamic courses and activities, delving into current student issues around community building, race, and cultural transformations.

Correspondence concerning this article should be addressed to Meekyung Han, School of Social Work, College of Applied Sciences and Arts, One Washington Square, San Jose State University, San Jose, CA 951920124;mhan@casa.sjsu.edu

\section{REFERENCES}

Abela, J. R. Z., \& Hankin, B. L. (2008). Handbook of depression in children and adolescents. New York: Guilford Press.

Alvarez, A. N., \& Liu, W. M. (2002). Student affairs and Asian American studies: An integrative perspective. New Directions for Student Services, 97, 73-80.

Amrsden, G., \& Greenberg, M. (1987). The Inventory of Parent and Peer Attachment: Individual differences and their relationship to psychological well-being in adolescence. Journal of Adolescent and Adolescence, 16, 427-454.

Antonovsky, A. (1979). Health, stress and coping. San Francisco: Jossey-Bass.

Antonovsky, A. (1987). Unraveling the mystery of health: How people manage stress and stay well. San Francisco: Jossy-Bass.

Antonovsky, H., \& Sagy, S. (1986). The development of a sense of coherence and its impact on responses to stress situation. Journal of Social Psychology, 126(2), 213-225.

Arnett, J. J. (1999). Adolescent storm and stress reconsidered. American Psychologist, 54(5), 317-326.

Baron, R. M., \& Kenny, D. A. (1986). The moderatormediator variable distinction in social psychological research: Conceptual, strategic, and statistical considerations. Journal of Personality and Social Psychology, 51, 1173-1182.
Bowlby, J. (1973). Attachment and loss: Vol. 2: Separation. New York: Basic Books.

Bowlby, J. (1988). A secure base: Parent-child attachment and healthy human development. New York: Basic Books.

Carstens, J. A., \& Spangenberg, J. J. (1997). Major depression: A breakdown in sense of coherence? Psychology Review, 80, 1211-1220.

Choi, Y., He, M., \& Harachi, T. W. (2008). Intergenerational cultural dissonance parent-child conflict and bonding, and youth problem behaviors among Vietnamese and Cambodian immigrant families. Journal of Youth and Adolescence, 37(1), 85-96.

Clark, R., Anderson, N., Clark, V. R., \& Williams, D. R. (1999). Racism as a stressor for African Americans: A biopsychoosical model. American Psychologist, 54, 805-816.

Chung, R. H. G. (2001). Gender, ethnicity, and acculturation in intergenerational conflict of Asian American college students. Cultural Diversity and Ethnic Minority Psychology, 7(4), 376-386.

Dinh, K., Sarason, B., \& Sarason, I. (1994). Parent-child relationships in Vietnamese immigrant families. Journal of Family Psychology, 8, 471-488.

Dion, K. L. (2002). The social psychology of perceived prejudice and discrimination. Canadian Psychology, 43, 1-10. 
Dion, K. L. (2003). Prejudice, racism, and discrimination. In T. Milton \& M. J. Lerner (Eds.), Handbook of psychology: Personality and social psychology, Vol. 5 (pp. 507-536). New York: Wiley and Sons.

Garcia Coll, C., Lamberty, G., Jenkins, R., McAdoo, H. P., Crnic, K., Wasik, B. H., \& Vazquez Garcia, H. (1996). An integrative model for the study of the developmental competencies in minority children. Child Development, 67, 1891-1914.

Greenberg, M., Siegel, J., \& Leitch, C. (1984). The nature and importance of attachment relationship to parents and peers during adolescence. Journal of Youth and Adolescence, 12, 373-386.

Greenberg, E., Chen, C., Tally, S. R., \& Dong, Q. (2000). Family, peer, and individual correlates of depressive symptomatology among U.S. and Chinese adolescents. Journal of Counseling and Clinical Psychology, 68, 209-219.

Hahm, H. C., Lahiff, M., \& Guterman, N. B. (2003). Acculturation and parental attachment in Asian American adolescents' alcohol use. Journal of Adolescent Health, 33, 119-129.

Han, M. (2004). Impact of parental trauma on depression among Southeast Asian American college students. Doctoral dissertation. University of California, Berkeley.

Han, M., Chou, V., Novotny, S., \& Nguyen, M. (2007). Parental control, intergenerational conflict, and depression in Southeast Asian American young adults. Poster presented at the 53rd Annual Program Meeting of Council on Social Work Education (CSWE), San Francisco, CA.

Hankin, B. L., Abramson, L. Y., Moffit, E., Silva, P. A., McGee, R., \& Angell, K. E. (1998).Development of depression from preadolescence to young adulthood: Emerging gender differences in a 10-year longitudinal study. Journal of Abnormal Psychology, 107, 128-140.

Hinderlie, H. H., \& Kenny, M. (2002). Attachment, social support, and college adjustment among Black students at predominantly White universities. Journal of College Student Development, 43, 327-340.

Hsu, E., Davies, C., \& Hansen D. (2004). Understanding mental health needs of Southeast Asian refugees: Historical, cultural, and contextual challenges, Clinical Psychology Review, 24(2), 193-213.

Hunnum, J. W., \& Dvorak, D. M. (2004). Effects of family conflict, divorce, and attachment patterns on the psychological distress and social adjustment of college freshmen. Journal of College Student Development, 45, 27-42.

Kenny, M., \& Donaldson, G. (1991). Contribution of parental attachment and family structure to the social and psychological functioning of first-year college students. Journal of Counseling Psychology, 38, 479-486.

Kenny, M., \& Sirin, S. R. (2006). Parental attachment, selfworth, and depressive symptoms among emerging adults. Journal of Counseling and Development, 84(1), 61-71.

Kibria, N. (1993). Family tightrope: The changing lives of Vietnamese Americans. Princeton, NJ: Princeton University Press.

King, P. M., \& Baxter Magolda, M. B. (2005). A developmental model of intercultural maturity. Journal of College Student Development, 46, 571-592.

Laible, D., Carlo, G., \& Raffaelli, M. (2000). The differential relations of parent and peer attachment to adolescent adjustment. Journal of Youth and Adolescence, 29(1), 45-59.
Laible, D. J., Carlo, G., \& Roesch, S. C. (2004). Pathways to self-esteem in late adolescence: The role of parent and peer attachment, empathy, and social behaviors. Journal of Adolescence, 27, 703-716.

Lam, B. T. (2007). Impact of perceived racial discrimination and collective self-esteem on psychological distress among Vietnamese American college students: Sense of coherence as mediator. American Journal of Orthopsychiatry, 77, 370-376.

Landrine, H., \& Klonoff, E. A. (1996). The schedule of racist events: A measure of racial discrimination and a study of its negative physical and mental health consequences. Journal of Black Psychology, 22, 144-168.

Lee, R. M. (2003). Do ethnic identity and other-group orientation protect against discrimination for Asian Americans? Journal of Counseling Psychology, 50, 133-141.

Lee, R. M., Choe, J., Kim, G., \& Ngo, V. (2000). The construction of the Asian American Family Conflict Scale. Journal of Counseling Psychology, 47(2), 211-222.

Leinonen, J., Solantaus, T., \& Punamaki, R. (2003). Social support and the quality of parenting under economic pressure and workload in Finland: The role of family structure and parental gender. Journal of Family Psychology, 17, 409-418.

Liang, C. T. H., Li, L. C., \& Kim, B. S. K. (2004). The Asian American Racism-Related Stress Inventory: Development, factor analysis, reliability, and validity. Journal of Counseling Psychology, 51, 103-114.

Lopez, R. G., \& Brennan, K. A. (2000). Dynamic processes underlying adult attachment organization: Toward an attachment theoretical perspective on the healthy and effective self. Journal of Counseling Psychology, 47, 283-301.

Mallinckrodf, B. (2000). Attachment, social competencies, and interpersonal process in psychotherapy. Psychotherapy Research, 10, 239-266.

Major, B., Cramzow, R. H., McCoy, S., Levin, S., Schmader, T., \& Sidanius, J. (2002). Perceiving personal discrimination: The role of group status and legitimizing ideology. Journal of Personality and Social Psychology, 82, 269-282.

Marshall, G. ,Schell, T., Elliott, M., Berthold, M., \& Chun, C. (2005). Mental health of Cambodian refugees 2 decades after resettlement in the United States. Journal of American Medical Association, 294, 571-579.

McCarthy, C. J., Moller, N., \& Fouladi, R. (2001). Continued attachment to parents: Its relationship to affect regulation and perceived stress among college students. Measurement and Evaluation in Counseling and Development, 33, 198-213.

Mikulincer, M., \& Arad, D. (1999). Attachment, working models, and cognitive openness in close relationships: A test of chronic and temporary accessibility effects. Journal of Personality and Social Psychology, 77, 710-725.

Merz, E., Schuengel, C., \& Schulze, H. (2007). Intergenerational solidarity: An attachment perspective. Journal of Aging Studies, 21, 175-186.

Nolen-Hoeksema, S., \& Girgus, J. S. (1994). The emergence of gender differences in depression during adolescence. Psychological Bulletin, 115, 424-443.

Nyborg, V. M., \& Curry, J. F. (2003). The impact of perceived racism: Psychological symptoms among African American boys. Journal of Clinical Child and Adolescent Psychology, 32, 258-266. 
Pallant, J. F., \& Lae, L. (2002). Sense of coherence, wellbeing, coping and personality factors: Further evaluation of the sense of coherence scale. Personality and Individual Differences, 33, 39-48.

Phinney, J., \& Ong, A. (2002). Adolescent-parent disagreements and life satisfaction in families from Vietnamese- and European-American backgrounds. International Journal of Behavioral Development, 26, 556-561.

Radloff, L. (1977). The CES-D Scale: A self-report depressions scale for research in the general population. Applied Psychological Measurement, 1, 385-401.

Rice, K. G., Fitzgerald, D. P., Whaley, T. J., \& Gibbs, C. (1995). Cross-sectional and longitudinal examination of attachment, separation-individuation, and college student adjustment. Journal of Counseling and Development, 73, 463-474.

Sagy, S., \& Antonovsky, H. (2000). The development of the sense of coherence: A retrospective study of early life experiences in the family. Journal of Aging and Human Development, 51(2), 155-166.

Scott, L. D. (2003). The relation of racial identity and racial socialization to coping with discrimination among African American adolescents. Journal of Black Studies, 33, 520-538.

Southeast Asian Reaction Center. (2004). Southeast Asian American statistical profile. Retrieved from http://www.searac .org/sites/default/files/seastatprofilemay04.pdf

Steinberg, L. (2001). We know some things: Parent-adolescent relationships in retrospect and prospect. Journal of Research on Adolescence, 11, 1-19.

Stone, S., \& Han, M. (2005). Perceived school environments, perceived discrimination, and school performance among children of Mexican immigrants. Children and Youth Services Review, 27(1), 51-66.

Sue, D. W., \& Sue, D. (2009). Counseling the culturally different: Theory and practice (5th ed.). San Francisco: Wiley.

Suzuki, B. (2002). Revisiting the model minority stereotype: Implications for student affairs practice and higher education. New Directions for Student Services, 92, 21-32.

Szalacha, L. A., Erkut, S., Garcia Coll, C., Alarcon, O., Fields, J. P., \& Ceder, I. (2004). Discrimination and Puerto Rican children's and adolescents' mental health. Cultural Diversity and Ethnic Minority Psychology, 9(2), 141-155.
Thompson, C. E., \& Neville, H. A. (1999). Racism, mental health, and mental health practice. The Counseling Psychologist, 27, 155-223.

Um, K. (2003). A Dream Denied: Educational Experiences of Southeast Asian American Youth Issues and Recommendations. California: UC Berkeley.

U.S. Census Bureau. (2003). The foreign-born population in the United States: March 2002, P20-539. Washington DC: U.S. Department of Commerce.

U.S. Census Bureau. (2006). American community survey: Selected population profile in the United States. Retrieved from http://factfinder.census.gov/servlet/DatasetMainPageServlet? program $=$ ACS $\& \_s u b m e n u I d=\& \_l$ lang $=$ en $\& \_$ts $=$

von Bothmer, M., \& Fridlund, B. (2003). Self-rated health among university students in relation to sense of coherence and other personality traits. Scandinavian Journal of Caring Sciences, 17, 347-357.

Yeh, T. L. (2002). Asian American College Students who are educationally at risk. New Directions for Student Services, 97, 61-71.

Ying, Y. (2001). Psychotherapy with traumatized Southeast Asian refugees. Clinical Social Work Journal, 29(1), 65-78.

Ying, Y., \& Han, M. (2007). Familism and mental health: Variation between Asian American children of refugees and immigrants. International Journal of Applied Psychoanalytic Studies, 4, 333-348.

Ying, Y., Lee, P. A., Tsai, J. L., Yeh, Y., \& Huang, L. N. (2000). Conception of depression in Chinese American college students. Cultural Diversity and Ethnic Minority Psychology, 6, 186-195.

Ying, Y., \& Tracy, L. (2004). Psychometric properties of the Intergenerational Congruence in Immigrant Families-Parent Scale in Chinese Americans. Social Work Research, 28, 56-62.

Zhou, M., \& Bankston, C. L., III. (1998). Growing up American: How Vietnamese children adapt to life in the United States. New York: Russell Sage Foundation.

Zevalkink, J., Riksen-Walraven, J. M., \& Bradley, R. H. (2008). The quality of children's home environment and attachment security in Indonesia. The Journal of Genetic Psychology, 169(1), 72-91. 